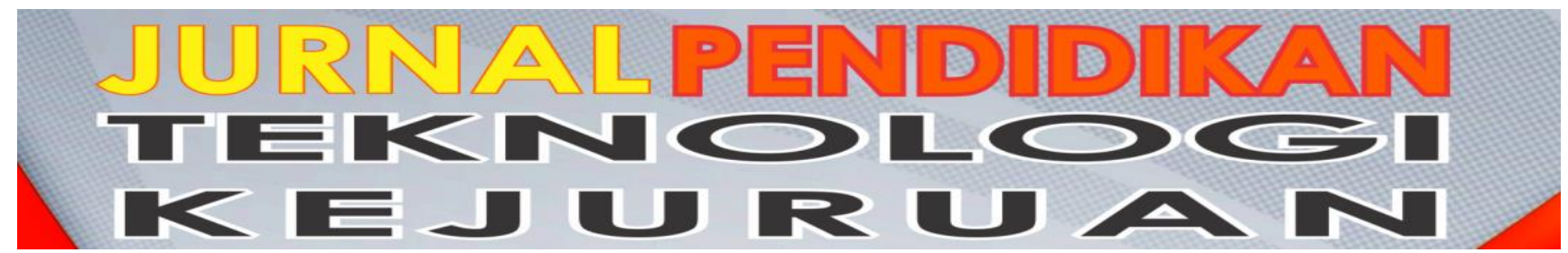

Vol. 4, No. 2, May 2021

P-ISSN: 2621-3273

E-ISSN: 2621-1548

\title{
Hotel Management Graduates Perception of Work Conditions and The Moderating Effect of Salary on Work Motivation in the Hotel Industry During the COVID- 19 Pandemic
}

\author{
Feri Ferdian $^{1 *}$, Youmil Abrian ${ }^{2}$, Hijriyantomi Suyuthie ${ }^{3}$, Ira Meirina Chair ${ }^{4}$ \\ ${ }^{1,2,3,4}$ Faculty of Tourism and Hospitality, Universitas Negeri Padang \\ *Corresponding author: feri_ferdian@fpp.unp.ac.id
}

\begin{abstract}
This study is based on the problem of decreasing hotel revenue which indicates a decrease in employee motivation as well as hotel management graduates to work in the hotel industry. This study aimed to analyze the hotel management graduates' perception of work conditions and the moderating effect of salary on work motivation in the hotel industry during the COVID- 19 pandemic. This research was conducted with a quantitative approach. The total population was 670 hotel management graduates with the sample's determination based on the type of purposive sampling. The sample size of the study is $20 \%$ of the total population (134 graduates) who are estimated to work in the hotel industry. A total of 134 respondents were successfully collected. The data analysis technique used is Partial Least Square Structural Equation Modelling (PLS-SEM). The results showed that: There is a significant effect of work condition toward hotel management graduates' work motivation in the hotel industry during the COVID- 19 pandemic and there is a significant moderating effect of salary toward the relationship between work condition (calm, cleanliness, air exchange, lighting, and security) and hotel management graduates' work motivation (seriousness in completing the work, responsibility, the need for good performance, perseverance at work, and worrying about failure) in the hotel industry during the COVID- 19 pandemic. What could be said from the result of the study is that the impact of work conditions toward work motivation in the hotel industry during the COVID-19 pandemic would be increased with the presence of salary.
\end{abstract}

Keyword: Work Condition, Salary, Work Motivation, COVID-19 Pandemic

\section{INTRODUCTION}

The hotel industry is one of the industries that has slumped as a result of the impact of the COVID-19 pandemic. With the decline in the number of tourists coming to Indonesia, of course, it will have an impact on the quantity of hotel product purchases. Hotels generally get consumers from tourists who come, but with the COVID-19 pandemic, the amount of hotel revenue will decrease. The decline in hotel revenues that occurred due to the COVID19 pandemic was in the range of $13 \%-49 \%$ (Frihatni et al., 2021). Along with a decrease in the amount of hotel income, it will certainly have an impact on the benefits received by employees. The downturn in the hospitality business raises the question of whether employees who will remain motivated work in hotels or look for better job alternatives.
The decrease in employee motivation at the hotel will certainly have an impact on performance achievement. Employees who work with low motivation certainly cannot support hotel management in achieving goals (Al Banin et al., 2020; Riyanto et al., 2017). During the COVID-19 pandemic, hotels must be able to survive and compete with other hotel industries in getting guests to stay. Because hotels have operational costs that must be incurred every day, month, and even year in the operational period. With this pandemic, employees should have more strong motivation and innovative thinking in generating ideas to help hotels survive in carrying out their operations.

In the conditions of the COVID-19 pandemic, working conditions are one of the variables that have changed from usual. Working conditions are conditions felt by employees where employees work 
(Fisher \& Yuan, 1998; Qarri \& Fejza, 2018; Schütte et al., 2014). Working conditions that used to feel comfortable and safe, have now changed with feelings of concern for the safety of employees at work. In addition, employees must ensure that the working conditions must be really clean and also need to ensure adequate ventilation space for air exchange. The COVID-19 virus will spread faster if there is no good air exchange in the room. Work conditions that are not good felt by employees will make employees less enthusiastic and passionate about work. This will affect the achievement of employee performance. In measuring working conditions in the service industry the indicators used are calm, cleanliness, air exchange, lighting, and security (Willyams, 2010).

The employee's drive to work better is supported by the receipt of a salary that is sufficient for the employees' living needs (Hariyono, 2021). When the salary received by employees is in accordance with what they expect, of course, they will work even harder in achieving goals (Vogt et al., 2020). However, with the COVID-19 pandemic, of course, salaries in the hotel industry are experiencing problems both in terms of quantity and in terms of payment (Saputra, 2021). Whereas most researchers claim that salary is a factor that strengthens employees' motivation to stay in the hotel industry (Lei et al., 2021; Sari et al., 2019).

With this scenario, several questions arise; (1) What is the effect of work conditions (calm, cleanliness, air exchange, lighting, and security) toward hotel management graduates' work motivation (seriousness in completing the work, responsibility, the need for good performance, perseverance at work, and worrying about failure) in the hotel industry during the COVID-19 pandemic? (2) The moderating effect of salary on the relationship between work conditions toward hotel management graduates' work motivation in the hotel industry during the COVID-19 pandemic? Previously published studies have mainly focused on employee performance (Faraj et al., 2021; Karakaş \& SAHIN, 2017; Laškarin Ažić, 2017; Saban et al., 2020; Soelton, 2018), job satisfaction (Ashton, 2018; Jiang \& Lok, 2021; Reidhead, 2020; Tejayadi et al., 2019; Yoopetch et al., 2021) turnover intention (Alom et al., 2019; Koo et al., 2020; Li et al., 2019; Nor et al., 2017; Wen et al., 2020) and working commitment (AlKahtani et al., 2021; Farrukh et al., 2020; Rabiul et al., 2021; Sarhan et al., 2020; Yao et al., 2019). However, there is a lack of studies that focus on how salary moderates the relationship between work conditions and hotel management graduates' work motivation in the hotel industry during the COVID19 pandemic.

\section{METHOD}

This research was conducted with a quantitative approach. The total population was 670 hotel management graduates. The sampling technique used in this study is purposive sampling. The sample criteria used were graduates of Universitas Negeri Padang Hospitality Management who work in the hotel industry. The sample size in this study is estimated at $20 \%$ of the total population (134 graduates), the reason that this percentage is estimated to be the number of hospitality management graduates who work specifically in the hotel industry. A total of 134 respondents were successfully collected. The type of data used is primary and secondary data. The data collection technique was conducted through a questionnaire with an online survey. The variables of the study are work conditions (independent variable), salary (moderating variable), and work motivation (dependent variable). The instrument in this study was a Likert scale. The inferential analysis technique in this study used PLS-SEM (Partial Least Square Structural Equation Modelling).

\section{RESULT}

PLS-SEM was used of two components: the measurement and the structural model.

\section{Measurement Model}

The model reliability and convergent validity were assessed through factor loadings, composite reliability (CR), and average variance extracted (AVE). A measurement model was undertaken, and the result as shown in figure 1 and Table 1 reports the outer loading, indicator reliability, composite reliability, AVE scores, and the Cronbach Alpha value.

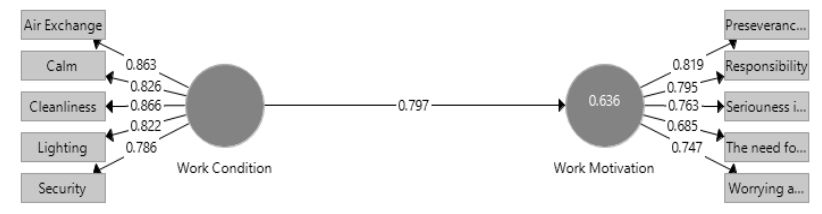

Figure 1. Measurement Model

Table 1. Measurement Model

\begin{tabular}{lccccc}
\hline $\begin{array}{c}\text { Latent } \\
\text { Variable }\end{array}$ & Indicators & $\begin{array}{c}\text { Outer } \\
\text { Loadings }\end{array}$ & $\begin{array}{c}\text { Cronbach Composite } \\
\text { Alpha }\end{array}$ & Reliability & AVE \\
\hline \multirow{3}{*}{ Work } & Calm & 0.862 & 0.890 & 0.919 & 0.694 \\
Condition & Cleanliness & 0.866 & & & \\
& Air Exchange & 0.863 & & & \\
& Lighting & 0.822 & & & \\
\hline
\end{tabular}




\begin{tabular}{|c|c|c|c|c|c|}
\hline & Security & 0.786 & & & \\
\hline \multirow{5}{*}{$\begin{array}{c}\text { Work } \\
\text { Motivation }\end{array}$} & $\begin{array}{l}\text { Seriouness in } \\
\text { Completing the } \\
\text { work }\end{array}$ & 0.763 & \multirow[t]{5}{*}{0.823} & \multirow[t]{5}{*}{0.874} & \multirow[t]{5}{*}{0.582} \\
\hline & Responsibility & 0.795 & & & \\
\hline & $\begin{array}{l}\text { The need for } \\
\text { good } \\
\text { performance }\end{array}$ & 0.685 & & & \\
\hline & $\begin{array}{c}\text { Perseverance at } \\
\text { work }\end{array}$ & 0.819 & & & \\
\hline & $\begin{array}{l}\text { Worrying about } \\
\text { failure }\end{array}$ & 0.747 & & & \\
\hline
\end{tabular}

Based on Table 1, Cronbach's Alpha value of work condition 0.890 and work motivation 0.823 , while the composite reliability value of work condition 0.919 , and work motivation 0.874 , this indicates that internal consistency reliability is accepted because Cronbach's Alpha value and composite reliability are higher than 0.70. Next, all items loaded are also acceptable significantly (outer loadings ranging from 0.685 to 0.866 ) onto their respective factors, verifying their indicator reliability. The measurement model used to collect respondents' data had sufficient convergent validity based on the AVE values. The AVE values of work condition (0.694) and work motivation (0.582) were well above the required minimum level of 0.50

The last of the measurement model evaluation is to assess discriminant validity using The Heterotrait-Monotrait Ratio of Correlations (HTMT) analysis. The HTMT value in Table 2 indicated no discriminant validity problem (HTMT $<0.85$ criterions). This implied that the HTMT criterion did not detect collinearity issues among the latent constructs.

Table 2. HTMT assessment

\begin{tabular}{lcc}
\hline & $\begin{array}{c}\text { Work } \\
\text { Motivation }\end{array}$ & Work Condition \\
\hline Work Motivation & 1 & \\
\hline Work Condition & 0.819 & 1 \\
\hline
\end{tabular}

\section{Structural Model}

The second evaluation in the PLS-SEM analysis is the structural modeling or path analysis in response to the proposed hypothesis. This research aims to establish the effect of work conditions toward work motivation in the hotel industry during the COVID19 pandemic. Table 3 reports the structural model with the result of path coefficients, T-statistic and significance levels of the proposed hypothesis (the result of Bootstrapping). The path coefficients are acceptable when their significance is at least at the 95\% confidence level. Based on the path analysis output (Table 3), all hypotheses are accepted.
Table 3. Path Coefficients, Observed T-statistics and Significance Levels

\begin{tabular}{llcccc}
\hline & Path Analysis & $\begin{array}{c}\text { Path } \\
\text { Coefficient } \\
\mathrm{B}\end{array}$ & $\begin{array}{c}\mathrm{T} \\
\text { Statistics }\end{array}$ & $\begin{array}{c}\mathrm{P} \\
\text { Values }\end{array}$ & Result \\
\hline $\mathrm{H}_{1} \quad \begin{array}{l}\text { Work Condition } \\
\text { - Work } \\
\text { Motivation }\end{array}$ & 0.800 & 31.633 & 0.000 & Accept \\
\hline$* p<.05, * * p<.01, * * * p<0.001$ & &
\end{tabular}

The results of the path coefficients which respond to the hypotheses showed that work conditions are showing a positive significant effect on the work motivation in the hotel industry during the COVID19 pandemic $(\beta=0.800$ and $t=31.633)$.

The results coefficient of determination $\left(\mathrm{R}^{2}\right)$ showed a substantial amount of variance $\left(\mathrm{R}^{2}\right.$ values 0.636$)$ work motivation in the hotel industry during the COVID-19 pandemic that can be explained by the proposed predictor (work condition). Referring to Figure 1 the work condition was able to explain $63.6 \%\left(\mathrm{R}^{2}=0.636\right)$ of the variance in the job of the variance in the work motivation in the hotel industry. The effect size function $\left(f^{2}\right)$, which is similar to the traditional partial F-test, explains the increases in $\mathrm{R}^{2}$ relative to the proportion of variance of the dependent variable that remains unexplained. In Table 4 , the $f^{2}$ column revealed that the relations presented effect sizes.

Table 4. $f^{2}-$ Factor of the research model

\begin{tabular}{lcc}
\hline & $f^{2}$ Work Motivation & Effect size \\
\hline Work & 1.744 & Susbtansial \\
\hline Condition & &
\end{tabular}

Notes: $\mathrm{f}^{2}$ values of $0.02=$ weak; $0.15=$ moderate; and $0.35=$ substantial.

The result from Table 4 above, there is a substantial effect for the significant paths of work conditions toward work motivation in the hotel industry during the COVID-19 pandemic.

Values of $\mathrm{q}^{2}$ of $0.02,0.15$, and 0.35 indicate that exogenous constructs as small, medium, or large predictive relevance for a selected endogenous construct (Hair et al., 2011). The result of test predictive relevance $\left(\mathrm{q}^{2}\right)$ is illustrated in Table 5 .

Table 5. Test of predictive relevance (q2)

\begin{tabular}{lc}
\hline Independent Variable & Work Motivation \\
\hline Work Condition & 0.356 \\
\hline
\end{tabular}

The result for $\mathrm{q} 2$ is explained in Table 5. An omission distance of seven implies that every 7 data points of the target construct are eliminated in a single blindfolding round. Using the omission distance of 7 , this study obtains a $\mathrm{q}^{2}$ 
value of 0.356 for work motivation in the hotel industry, which is the work motivation in the hotel industry during the COVID-19 pandemic indicative of a large predictive model. The higher the value of $\mathrm{q}^{2}$, the greater is the predictive relevance of the structural model. In this sense, the independent variable proposed in this study are predictors for work motivation in the hotel industry during the COVID-19 pandemic.

\section{Moderating Effects}

Based on the theoretical reasoning that suggests salary as the moderating factor influencing graduates' career commitment construct. Table 6 summarises the result.

Table 6. Moderating effect of salary
Beta Standard T P P Result Work

Condition+

$\begin{array}{llllll}\text { Moderate - } & 0.199 & 0.052 & 1.427 & 0.000 & \text { Significant }\end{array}$

$>$ Work

Motivation

Based on the result, the moderator variable was significantly correlated to the relationship between the work condition and work motivation $(\beta=0.199)$. It can be concluded that there is an interaction effect of salary between work conditions and work motivation in the hotel industry during the COVID-19 pandemic.

\section{DISCUSSION}

The Effect of Work Condition Toward Hotel Management Graduates Work Motivation in The Hotel Industry During the COVID-19 Pandemic

$\mathrm{H}_{1}$ as the first hypothesis proposed a causal relationship between work conditions and work motivation in the hotel industry during the COVID19 pandemic. This proposition made is based on the belief that work conditions could influence work motivation in the hotel industry during the COVID19 pandemic. The result showed a significant influence of work conditions toward work motivation in the hotel industry during the COVID19 pandemic $(\beta=0.800$ and $t=31.633, p<0.05)$ and thus supported hypothesis $\mathrm{H}_{1}$ of the study. This result, in general, demonstrated that work condition has given a significant impact on the hotel management graduates' work motivation in the hotel industry during the COVID-19 pandemic. This finding is consistent with Qarri and Fejza (2018) working conditions as motivation for employees. This result is also in line with Le et al. (2021) and $\mathrm{Lu}$ et al. (2021) that working conditions influence 68 work motivation. For further research, it is recommended to examine how to maintain employee motivation to work in hotels with good performance.

The Moderating Effect of Salary Toward the Relationship between Work Condition and Hotel Management Graduates Work Motivation in The Hotel Industry During the COVID-19 Pandemic

The finding of $\mathrm{H}_{2}$ produced that the salary moderates the relationship between work conditions and work motivation in the hotel industry. This can be seen with the $\beta$ : 0.199 , tvalue: $1.427, \mathrm{p}<0.01$ which is significant. Thus, essentially the hypothesis $\mathrm{H}_{2}$ is supported. The positive beta value indicates that the relationship between work conditions and work motivation in the hotel industry is increased with the presence of the salary. In other words, the salary is giving many effects on the relationship between the work condition and work motivation in the hotel industry. In the real term, the salary has given a positive indicator on the hotel management graduates' work motivation in the hotel industry during the COVID-19 pandemic despite there being work conditions felt. Hotel management graduates still have a strong motivation in the hotel industry supported by the competitive salary compared to other service industries that have felt the impact of the COVID-19 pandemic so that the relationship between working conditions and work motivation is getting stronger. This strong motivation is also driven by the limited number of jobs available in Indonesia due to the demographic bonus which makes it more difficult to get a job in Indonesia, especially during the COVID-19 pandemic, so hotel management graduates have a strong urge to stay in the hotel industry. Even with the COVID-19 pandemic, it is hoped that hotel management will continue to pay attention to the welfare of employees so that good employee performance is maintained.

\section{CONCLUSION}

From the overall findings, it is evident that work condition does clearly give an effect on hotel management graduates' work motivation in the hotel industry during the COVID-19 pandemic. The result of the study also found that salary succeeded in moderating the relationship between work 
conditions and work motivation in the hotel industry during the COVID-19 pandemic. Hotel management graduates may feel that their working conditions meet their expectations and thus have a strong motivation to work in the hospitality industry. Likewise, salaries have succeeded in improving the relationship between working conditions and the motivation of hotel management graduates to work in the hospitality industry during the COVID-19 pandemic, because the salaries they receive are still able to meet their daily needs compared to other industries affected by the COVID-19 pandemic. The context of hotel management graduates at Universitas Negeri Padang where most of the hotel management graduates who are motivated to work in the hospitality industry during the COVID-19 pandemic do have an interest in the good working conditions of this industry compared to other industries such bank, restaurant, coffee shop and many others. The implication of this research is that it is recommended that future research be carried out related to job retention, job embeddedness, environment turbulence and others.

\section{REFERENCES}

Al Banin, Q., Eliyana, A., \& Latifiyah, E. R. (2020). Enhancing employee performance with work motivation as a mediation variable. Systematic Reviews in Pharmacy, 11(9), 333-346.

AlKahtani, N., Iqbal, S., Sohail, M., Sheraz, F., Jahan, S., Anwar, B., \& Haider, S. (2021). Impact of employee empowerment on organizational commitment through job satisfaction in four and five stars hotel industry. Management Science Letters, 11(3), 813-822.

Alom, S., Patwary, A. K., \& Khan, M. M. H. (2019). Factors affecting the turnover intention of Bangladeshi migrants in the United Arab Emirates: An empirical study on the hotel industry. International Journal of Innovation, Creativity and Change, 8(3), 344-360.

Ashton, A. S. (2018). How human resources management best practice influence employee satisfaction and job retention in the Thai hotel industry. Journal of Human Resources in Hospitality \& Tourism, 17(2), 175-199.

Faraj, K. M., Faeq, D. K., Abdulla, D. F., Ali, B. J., \& Sadq, Z. M. (2021). Total Quality Management And Hotel Employee Creative Performance: The Mediation Role Of Job Embeddedment. Journal of Contemporary Issues in Business and Government, 27(1), 3838-3855.

Farrukh, M., Kalimuthu, R., Farrukh, S., \& Khan, M. S. (2020). Role of Job satisfaction and organizational commitment in Employee Loyalty: Empirical Analysis from Saudi Hotel Industry. Int. J. Bus. Psychol, 2, 1-20.

Fisher, C. D., \& Yuan, X. Y. (1998). What motivates employees? A comparison of US and Chinese responses. International Journal of Human Resource Management, 9(3), 516-528.

Frihatni, A. A., Sudirman, I., \& Mandacan, F. (2021). Analisis Kinerja Keuangan Perhotelan Akibat Pandemi Covid-19. Jurnal Ilmiah Mandala Education, 7(3).

Hair, J. F., Ringle, C. M., \& Sarstedt, M. (2011). PLSSEM: Indeed a Silver Bullet. Journal of Marketing Theory and Practice, 19(2), 139-152. https://doi.org/10.2753/MTP1069-6679190202

HARIYONO, H. (2021). Do Economic Attitudes Drive to Employee Productivity? Lesson from Indonesia. The Journal of Asian Finance, Economics, and Business, 8(1), 1009-1016.

Jiang, Y., \& Lok, R. R. H. (2021). Hotel employee satisfaction in the digital era: an exploratory study. Anatolia, 32(2), 330-333.

Karakaş, A., \& SAHIN, N. (2017). The relation between work family conflict and employee performance: a research on hotel employee. Sosyoekonomi, 25(32), 51-69.

Koo, B., Yu, J., Chua, B.-L., Lee, S., \& Han, H. (2020). Relationships among emotional and material rewards, job satisfaction, burnout, affective commitment, job performance, and turnover intention in the hotel industry. Journal of Quality Assurance in Hospitality \& Tourism, 21(4), 371401.

Laškarin Ažić, M. (2017). The impact of hotel employee satisfaction on hospitability performance. Tourism and Hospitality Management, 23(1), 105-117.

Le, D., Aquino, P., Truc, N., Si, L., \& My, L. (2021). Factors affecting employees' motivation. Management Science Letters, 11(4), 1063-1070.

Lei, C., Hossain, M. S., Mostafiz, M. I., \& Khalifa, G. S. A. (2021). Factors determining employee career success in the Chinese hotel industry: A perspective of Job-Demand Resources theory. Journal of Hospitality and Tourism Management, 48, 301-311.

Li, J. J., Bonn, M. A., \& Ye, B. H. (2019). Hotel employee's artificial intelligence and robotics awareness and its impact on turnover intention: The moderating roles of perceived organizational support and competitive psychological climate. Tourism Management, 73, 172-181.

Lu, L., Chou, C. Y., \& Cooper, C. L. (2021). Personal and social resources in coping with long hours of the Chinese work condition: the dual roles of detachment and social motivation. The 
International Journal of Human Resource Management, 1-35.

Nor, M. N. M., Nor, A. N. M., Ahmad, Z., Khalid, S. A., \& Ibrahim, I. I. (2017). Factors affecting turnover intention among gen $\mathrm{Y}$ in hotel industry. Jurnal Intelek, 12(1).

Qarri, H., \& Fejza, J. (2018). Working conditions as motivation for employees. Knowledge International Journal, 28(1), 341-344.

Rabiul, M. K., Patwary, A. K., Mohamed, A. E., \& Rashid, H. (2021). Leadership Styles, Psychological Factors, and Employee Commitment to Service Quality in the Hotel Industry. Journal of Quality Assurance in Hospitality \& Tourism, 1-29.

Reidhead, C. (2020). Impact of organizational culture on employee satisfaction: A case of Hilton hotel, United Kingdom. Journal of Economics and Business, 3(1).

Riyanto, S., Sutrisno, A., \& Ali, H. (2017). The impact of working motivation and working environment on employees performance in Indonesia stock exchange. International Review of Management and Marketing, 7(3), 342-348.

Saban, D., Basalamah, S., Gani, A., \& Rahman, Z. (2020). Impact of Islamic work ethics, competencies, compensation, work culture on job satisfaction and employee performance: the case of four-star hotels. European Journal of Business and Management Research, 5(1).

Saputra, I. K. E. D. (2021). ANALISIS HUKUM PEMUTUSAN HUBUNGAN KERJA PADA MASA PANDEMI COVID-19. Jurnal Ilmiah Raad Kertha, 4(2), 62-76.

Sarhan, N., Harb, A., Shrafat, F., \& Alhusban, M. (2020). The effect of organizational culture on organizational commitment: Evidence from the hotel industry. Management Science Letters, 10(1), 183-196.

Sari, N. P. R., Bendesa, I. K. G., \& Antara, M. (2019). The influence of quality of work-life on employees' performance with job satisfaction and work motivation as intervening variables in starrated hotels in Ubud tourism area of Bali. Journal of Tourism and Hospitality Management, 7(1), 7483.

Schütte, S., Chastang, J.-F., Malard, L., Parent-Thirion, A., Vermeylen, G., \& Niedhammer, I. (2014). Psychosocial working conditions and psychological well-being among employees in 34 European countries. International Archives of Occupational and Environmental Health, 87(8), 897-907.

Soelton, M. (2018). How culture, training standard and discipline on the employee performance affect hotel management. European Research Studies Journal, 21(4), 378-385.

Tejayadi, I. P. W., Laba, I. N., \& Pradana, G. Y. K. (2019). The effect of organizational culture on employee satisfaction in Mercure Resort Sanur. International Journal of Green Tourism Research and Applications, 1(1), 63-72.

Vogt, K. C., Lorentzen, T., \& Hansen, H.-T. (2020). Are low-skilled young people increasingly useless, and are men the losers among them? Journal of Education and Work, 33(5-6), 392-409.

Wen, B., Zhou, X., Hu, Y., \& Zhang, X. (2020). Role stress and turnover intention of front-line hotel employees: the roles of burnout and service climate. Frontiers in Psychology, 11, 36.

Willyams, U. (2010). Pengaruh Kondisi Kerja, Hubungan Kerja dan Kepuasan Kompensasi Terhadap Kinerja Karyawan [Universitas Sanata Dharma]. https://repository.usd.ac.id/14105/2/042214035_Fu 11.pdf

Yao, T., Qiu, Q., \& Wei, Y. (2019). Retaining hotel employees as internal customers: Effect of organizational commitment on attitudinal and behavioral loyalty of employees. International Journal of Hospitality Management, 76, 1-8.

Yoopetch, C., Nimsai, S., \& Kongarchapatara, B. (2021). The Effects of Employee Learning, Knowledge, Benefits, and Satisfaction on Employee Performance and Career Growth in the Hospitality Industry. Sustainability, 13(8), 4101. 